\title{
SIMPLICITY OF RUNNING BUSINESS IN GEORGIA - PRESENT AND FUTURE DEVELOPMENT
}

\begin{abstract}
Creating favorable conditions for the development of the private sector - and in such a way that the poorest sections of the population can benefit from it - suggests the creation of appropriate business regulation conditions under which new vigorous entrepreneurs, regardless of gender and national origin, who have promising ideas, will be able to open enterprises, firms will be able to invest and develop, creating additional jobs. To carry out business activities, effective rules are required - norms that establish and clarify property rights, ensure a reduction in the costs associated with resolving disputes; norms that ensure the predictability of business transactions and the trust of partners, protection from abuse. Comprehensive criteria for monitoring business development have been developed by the World Bank and every year they conduct a corporate survey of managers of various firms (World Bank's Doing Business project). The purpose of the research is to ensure the adoption of rules that are effective, information about which is accessible to all and which are easy to apply.

In the following paper, I tried to answer the question which is interesting many foreign investors - it easy to run a business in Georgia? To answer this question, I used World Bank Doing Business project. The aim of the study is only to provide the leading business representatives with an evidence base for policy development and public data to study the impact of business regulation systems on economic outcomes such as productivity, investment, reducing bureaucracy, corruption, unemployment, poverty etc.
\end{abstract}

Keywords: Competitiveness, Country's Strategy, Ranking, Assessment Criteria, International Business.

\section{INTRODUCTION}

The simplicity of starting a business in the country (generally in the world) and therefore its business strategy depends on the business environment of the country, which in turn contributes to the growth of the economy and the growth of private sector. The economic environment of Georgia is evaluated annually by various international and local organizations. Estimates of international organizations are mainly based on reports, new laws and legislative amendments. These assessments are not directly related to entrepreneurs'

\footnotetext{
${ }^{1}$ Ioseb Masurashvili, Doctor in Economics \& Management, Head of Innovation Management Center Faculty Economics\&Business at Javakhishvili Tbilisi State University; e-mail: ioseb. masurashvili@tsu.ge.

Ioseb Masurashvili, doktor nauk ekonomicznych i zarządzania, kierownik Centrum Zarządzania Innowacjami Wydział Ekonomii i Biznesu, Tbiliski Uniwersytet Państwowy im. Iwane Dżawachiszwilego; e-mail: ioseb.masurashvili@tsu.ge.
} 
opinions and specific problems. The business environment is a social, technological, economic and political environment that affects the company's decisions, strategies, processes and ultimately determines business opportunities. There is a long way to form a successful business environment in the country, and also there is a need for strong institutions, stable legislative regulation, and perhaps the most important: the existence of strong culture and traditions of running a business.

The position of international organizations, local experts and Georgian entrepreneurs is common in that the business environment has been significantly improved over the last few years. In general, doing business in Georgia is relatively simplified. In assessing business environment, the attractiveness of foreign investors should be taken into account. To attract large financial resources, first of all it's necessary to ensure stability. No matter how low the tax rate will be, if there is no stable legislative and political environment in the country, it will be impossible to talk about the developed business environment.

Development of business environment of Georgia is characterized by a positive trend, mainly caused by legislative reforms (tax, customs, licenses and permits etc.). It's necessary to improve and simplify the procedural parts of the legislative sphere and increase the level of relevant references.

The role of the state is naturally important for ensuring the success of the country's economy, but it is important to achieve the success of the environment and other sectors of the society - the media, the NGOs and the private sector.

Despite the trends in the improvement of the business environment, the Georgian business climate continues to face a number of challenging challenges ${ }^{2}$, with the establishment of a well-organized dialogue between the state and the private sector.

The objectives of state extraterritorial strategies may include the anchoring of global production networks in a state (especially the command and control functions of these networks), the opening of export markets to support the domestic agglomeration of production for export, and the stimulation of outward FDI to extend supply chains from the home market ${ }^{3}$. State capacities to pursue such strategic goals are geographically uneven, and underdevelopment constrains the set of strategic options for extraterritorial accumulation relative to the options of advanced capitalist states ${ }^{4}$.

Many problems of international firms, which doing business, arise the greater part as the result of a general policy adopted by the states by which they attempt to exclude all outsiders from engaging commercial activities in their boundaries ${ }^{5}$. The business which must be transacted by a foreign corporation to permit service of process must be such as to warrant the inference that the corporation is present. To subject such a corporation to

2 A. Rzepka, I. Masurashvili, Strategic perspectives for Georgian business - an analysis for medium - sized enterprises in EU and Georgia, "Modern Management Review 2016", Vol. XXI, 23 (3/2016), p. 115-129.

${ }^{3}$ N.A. Phelps, M. Power, R. Wanjiru, Learning to compete: Communities of investment promotion practice in the spread of global neoliberalism [In:] Neoliberalization: States, networks, peoples, ed. K. England, K. Ward, Malden, 2007, p. 375-376.

${ }^{4}$ S. Schueth, Assembling International Competitiveness: The Republic of Georgia, USAID, and the Doing Business Project, "Economic Georgrafy" 2011, Vol. 87, No. 1, p. 55.

5 A. Rzepka, Inter-organizational relations and their influence on the innovativeness of enterprises in the Podkarpackie region, Development Economics and Innovation: Challenges and Solutions, Proceedings of Materials of 4th International Scientific and Practical Conference (29-30 September 2017), Tbilisi 2017, p. 101-106. 
taxation for doing business, the transactions must not only show that the corporation is present but also that it is active. In order that qualification be rendered necessary, the corporation must not only be present and active, but its activity must be continuous ${ }^{6}$.

Last years two broad sets of facts about regulation of international firms in the developing countries have been established through both cross national and individual country research. I agree Mary Hallward-Driemeier and Lant Pritch, that the first set of facts, established through sources including the „Doing Business” indicators from the World Bank, is that firms that attempt full regulatory compliance will face an extremely costly and time-consuming process. The second set of facts from a variety of sources shows that in practice, firms in developing countires are often able to sidestep the "de jure" legal rules, which makes intuitive sense because many developing countries have low rankings by international standarts in categories like „role of law”, ,bureaucratic quality”, „government effectiveness" and control of corruption ${ }^{7}$.

Evidence on the de jure legal and regulatory requirements facing firms often draw on evidence from the World Bank's Doing Business project, which in turn is built on the pioneering work of De $\operatorname{Soto}^{8}(1989)$ in Peru and others? .

\section{WORD BANK'S DOING BUSINESS PROJECT}

Effective development international communication is the result of a logical series of steps that demands a consistent approach. The steps are defining goals, identifying, stakeholders, and developing messages. The great importance of functioning official and regulatory system in creating contemporary high effective global market economy is now large accepted.

Simplicity of doing business - Creating favorable environmental conditions for investments (security in the country, tax payments, corruption indexes, business registration terms, etc.) contributes to attracting foreign investors in the country, expanding existing corporations and establishing new companies, which leads to the development of international market relations and globalization processes.

There is scarcely a business pursued requiring the expenditure of large capital, or the union of large numbers, that is not carried on by corporations. It is not too much to say that the wealth and business of the country are to a great extent controlled by them. And if, when composed of citizens of one country, their corporate powers and franchises could be exercised in other countries without restriction, it is easy to see that with the advantages thus possessed, the most important business of those countries would soon pass into their hands. The principal business of every country would, in fact, be controlled by corporations created by other countries.

${ }^{6}$ Elcanon Isaacs, An Analysis of Doing Business, "Columbia Law Review" 1925, Vol. 25, No. 8, p. 1018-1045.

7 M. Hallward-Driemeier, L. Pritchett, How Business is Done in the Developing World: Deals versus Rules, "The Journal of Economic Perspectives" 2015, Vol. 29, No. 3, p. 121-140.

${ }^{8}$ H. De Soto, The Other Path: The Invisible Revolution in the Third World, London 1989.

${ }^{9}$ S. Djankov, R. La Porta, F. Lopez-De-Silanes, A. Shleifer, The Regulation of Entry, "Quarterly Journal of Economics 2002, 117(1); S. Djankov, R. La Porta, F. Lopez-de-Silanes, A, Shleifer, Courts, "Quarterly Journal of Economics" 2003, 118(2); S. Djankov, C. McLiesh, A. Shleifer, Private Credit in 129 Countries, "Journal of Financial Economics" 2007, 84(2). 
"As a result of this distrust on the part of countries the foreign corporation finds itself confronted by numerous disabilities when it enters another state to do business. For instance, it may be required to comply with the local ... tax laws which are also imposed on individuals and domestic corporations. It no doubt may be required to conform to restrictions which are placed only on parties which enter the country"10.

"It must often, in addition, submit to numerous burdens for which foreign corporations are especially singled out. These may be, among others, requirements that agents be appointed for service of process, discriminatory taxes, registration as a prerequisite of doing business, or preference of local creditors in the distribution of assets"11.

The Doing Business report collects data for a terrain over which there had been only scant knowledge previously... With such interest, it's no surprise that the Doing Business report has come under intense scrutiny. In 2012, following discussions by its board, the World Bank commissioned an independent review to evaluate the project... In broad terms, the Doing Business report has been criticized for the way in which the data are collected and whether they reflect the business and regulatory environment accurately. Concerns were raised about whether the construction of the survey fostered a "deregulation bias".

A measure of labor market regulation was a particular focus of concern, although this measure had already been removed from the set of measures used to determine aggregate rankings. Particular attention has focused on whether it is valid to collect the separate rankings into an aggregate ranking. A number of countries objected to being ranked at all.

Of course, alongside the peculiarities of the Doing Business report data, there are the usual concerns about the use of data that permeate empirical research in economics. Some researchers have used the data as a right-hand-side variable to "explain" outcomes of interest. Others put the data on the left-hand-side and ask how politics and institutions influence the business climate. In all cases, the usual concerns apply as to what inferences about causality can be drawn from such exercises. There is also a concern about the mapping from the Doing Business indicators to the conceptual categories that economic theory suggests ought to be important. Because so many researchers appear to equate "empirical evidence" with interpreting regression coefficients, this point merits discussion ${ }^{12}$.

Doing Business focuses on regulation that affects small and medium-size enterprises, operating in the largest business city of an economy, across 11 areas. Ten of these areas starting a business, dealing with construction permits, getting electricity, registering property, getting credit, protecting minority investors, paying taxes, trading across borders, enforcing contracts and resolving insolvency - are included in the distance to frontier score and ease of doing business ranking. Doing Business also publishes indicators on labor market regulation which are not included in the distance to frontier score or ease of doing business ranking. The economic literature has shown the importance of such regulations for firm and job creation, international trade and financial inclusion.

Doing Business presents quantitative indicators on business regulation and the protection of property rights that can be compared across more than 100 economies.

${ }^{10}$ Elcanon Isaacs, An Analysis..., p. 1018-1045.

${ }^{11}$ Ibidem, p. 1018-1045.

12 T. Besley, Law, Regulation, and the Business Climate: The Nature and Influence of the World Bank Doing Business Project, "The Journal of Economic Perspectives" 2015, Vol. 29, No. 3. p. 99-120. 
In 2018 year marks the World Bank 15th Doing Business report (reforming to create jobs) ${ }^{13}$, where it's possible to read, that - since the inception of the project in 2003 , the global business regulatory environment has changed dramatically. Governments around the world have embraced and nurtured advances in information technology to reduce bureaucratic hurdles and increase transparency. Today, in 65 of the 190 economies covered by Doing Business, entrepreneurs can complete at least one business incorporation procedure online, compared with only nine of the 145 economies measured in Doing Business 2004. Furthermore, in 31 economies it is now possible to initiate a commercial dispute online. This kind of progress can also be observed in the other areas measured by Doing Business. Doing Business measures aspects of business regulation and their implications for firm establishment and operations. It does not include all the issues that are relevant for businesses' decisions, but it does cover important areas that are under the control of policy makers. Governments worldwide recognize the economic and political benefits of improved business regulation. In fact, 119 of the 190 economies measured by Doing Business 2018 enacted at least one business regulation reform in 2016/17. Of these, $79.8 \%$ implemented at least one reform for a second consecutive year and $64.7 \%$ for a third.

Business regulation can enable new ideas to come to life. Conversely, in an economy where business regulation is cumbersome or ambiguous, it may be less willing to start their own company. In this case, the economy forfeits a new entrepreneur - as well as the associated capital investment and job creation. In turn, consumers have fewer, lower quality and more expensive product choices. Such a scenario highlights the way in which cumbersome regulation can distort resource allocation by stifling entrepreneurial endeavors in favor of maintaining a less optimal status quo.

Doing Business measures the processes for starting a business, obtaining a building permit, getting an electricity connection, transferring property, paying taxes, taking a commercial dispute to court, and resolving an insolvency case, as well as credit and equity market regulations and logistics of importing and exporting goods. There are many other factors that influence firm decisions - such as the availability of skilled labor or market size - that are not captured in Doing Business. But Doing Business focuses on key areas of interaction between the government and entrepreneurs, where policy makers and regulators can directly influence procedures to facilitate these interactions.

In addition, Doing Business measures the coverage, scope and quality of credit information available from credit registries and bureaus. When functioning well, these institutions form an essential element of an economy's financial infrastructure by strengthening access to financial services, particularly credit. By collecting and sharing credit information, such agencies reduce information asymmetries, increase access to credit for small firms, lower interest rates, improve borrower discipline and strengthen bank supervision and credit risk monitoring. Indeed, a study of a credit bureau serving the equipment finance industry in the United States found that better exchange of information between lenders results in improved repayment behavior by firms, including lower incidences of delinquencies and defaults.

This impact was stronger for firms that typically lack informational transparency, such as small and young firms.

\footnotetext{
${ }^{13} \mathrm{http} / / /$ www.doingbusiness.org/reports/global-reports/doing-business-2018 [access: 15.05.2018].
} 
Therefore, the rating of the countries Doing Business report is closely linked to the development of separate measures. I believe that each of these indicators needs deep analysis.

\section{SIMPLICITY OF DOING BUSINESS IN GEORGIA - PRESENT SITUATION}

Before October 1, 2012, it was a difficult situation in business administration of Georgia. After the change of government in Georgia, the attitude towards business changed radically ${ }^{14}$.

Start of business in Georgia today is very simple.

Ease of Doing Business Index $\left(\mathrm{EDBI}^{15}\right)$ is the global indicator of economic competitiveness. In this paper I use the World Bank's Doing Business data to capture the business environment.

Financial or procedural barriers are almost impossible for the enterprise to register. Financial resources are crucial for business expansion and, moreover, business start. No matter how easy it's to register the company, if the finances are not available, the most promising business idea will be doomed.

Under Georgian law, legal entities are divided into two broad categories: entrepreneurial legal entities and non-profit legal entities. Individuals may also conduct business as sole proprietors without establishing any separate legal entity. Companies are required to have their own name, management and registered offices. In addition to their legal address, entrepreneurial legal entities may submit to the registration authority information about an alternative legal address and email address. Companies established in Georgia are subject to Georgian law, but agreements concluded by Georgian companies can be governed by the law agreed to between the parties, unless otherwise determined by the Georgian Act of International Private Law. Foreigners can become a partner or be appointed as director of a Georgian company and they do not need a permit to do so. In case foreigner desires to become a partner in a company, that owns agricultural land, unofficial restrictions might apply.

Legal entities for carrying out business namely: The Georgian Entrepreneurs Act (1994) defines six types of legal entities that may carry out entrepreneurial activities: Sole proprietor; Limited Liability Company; Joint Stock Company; Cooperative; Joint Liability Company; Limited Partnership.

According to the 2018 Ease of Doing Business index (EDBI) Georgia is among the top 10 countries from 190 countries. Georgia has built one of the strongest business climates over the past years, fueled by low business costs and incentives. Among the top 20 economies, Georgia, with a ranking of 9 in 2018, 16 - in 2017, and 24 - in 2016 (table 1, 2, 3, 4),

${ }^{14}$ I. Masurashvili, Past and Future of Business Administration in Georgia, International Conference for Academic Disciplines, Cambridge, USA. May 26-30.2013, http://ijas2013harvard.sched. org/event/24724800be6a0b109e0ba718553d6344\#.UZUO3KKnzaQ

15 The ease of doing business index is an index created by Simeon Djankov at the World Bank Group. Higher rankings (a low numerical value) indicate better, usually simpler, regulations for businesses and stronger protections of property rights. Empirical research funded by the World Bank to justify their work show that the economic growth impact of improving these regulations is strong. https://en.wikipedia.org/wiki/Ease_of_doing_business_index [access: 15.05.2018]. 
has implemented the highest number of business regulation reforms since the launch of Doing Business in 2003 - a total of 47 (time for starting business was needed for 30 days ${ }^{16}$ ).

Getting credit is not the most serious problem facing businesses in any of the countries. For Georgia, doing business indicates that closing a business and getting electricity are the most important concerns. Other aspects of the business environment in Georgia are generally positive and the country scores particularly well for dealing with licenses, registering property and starting a business.

Table 1. Easy of Doing Business ranking (Top 20 economy)

\begin{tabular}{|c|c|c|c|}
\hline $\begin{array}{c}\text { DB } \\
2018 \\
\text { Rank }\end{array}$ & Economy & $\begin{array}{c}\text { DTF }^{17} \\
\text { score }\end{array}$ & $\begin{array}{c}\text { DTF } \\
\text { change }\end{array}$ \\
\hline 1 & 2 & 3 & 4 \\
\hline 1 & New Zealand & 86.55 & -0.18 \\
\hline 2 & Singapore & 84.57 & +0.04 \\
\hline 3 & Denmark & 84.06 & -0.01 \\
\hline 4 & Korea, Rep. & 83.92 & 0.00 \\
\hline 5 & Hong Kong SAR, & 83.44 & +0.29 \\
\hline 6 & China & 82.54 & -0.01 \\
\hline 7 & United States & 82.22 & -0.12 \\
\hline 8 & Norway & 82.16 & -0.25 \\
\hline 9 & Georgia & 82.04 & +2.12 \\
\hline 10 & Sweden & 81.27 & +0.03 \\
\hline
\end{tabular}

\begin{tabular}{|c|c|c|c|}
\hline $\begin{array}{c}\text { DB } \\
2018 \\
\text { Rank }\end{array}$ & Economy & $\begin{array}{c}\text { DTF } \\
\text { score }\end{array}$ & $\begin{array}{c}\text { DTF } \\
\text { change }\end{array}$ \\
\hline 1 & 2 & 3 & 4 \\
\hline 11 & Macedonia, FYR & 81.18 & -0.21 \\
\hline 12 & Estonia & 80.80 & +0.05 \\
\hline 13 & Finland & 80.37 & 0.11 \\
\hline 14 & Australia & 80.14 & 0.00 \\
\hline 15 & Taiwan, China & 80.07 & +0.41 \\
\hline 16 & Lithuania & 79.87 & +1.05 \\
\hline 17 & Ireland & 79.51 & -0.19 \\
\hline 18 & Canada & 79.29 & -0.09 \\
\hline 19 & Latvia & 79.26 & -0.79 \\
\hline 20 & Germany & 79.00 & -0.19 \\
\hline
\end{tabular}

Source: http://www.doingbusiness.org [access: 15.05.2018].

The Georgia is the only lower-middle-income one economy on the list, while Macedonia, Former Yugoslav Republic, is the only upper-middle-income (table 1). To date, no lowincome economy has reached the top 20 group. On Table 1, where it's possible to see, that from this top 20 group only Georgia has +2.12 (high) change in DTF.

From Table 2 it's possible to see that overall rank DTF (in 2017-2018) increased and changed by $2.12 \%$ (from 79.92 to 82.04 ), from here starting a business by $-0.01 \%$, dealing with Construction Permits $-0.02 \%$, Getting Electricity $-0.55 \%$, Protecting Minority Investors $-5 \%$, Paying Taxes $-0.04 \%$ and resolving insolvency ${ }^{18}-15.57 \%$.

${ }^{16} \mathrm{http} / / / \mathrm{www}$.doingbusiness.org/reports/global-reports/doing-business-2004 [access: 15.05.2018].

17 The distance to frontier (DTF) measure shows the distance of each economy to the "frontier," which represents the best performance observed on each of the indicators across all economies in the Doing Business sample since 2005. An economy's distance to frontier is reflected on a scale from 0 to 100, where 0 represents the lowest performance and 100 represents the frontier. The ease of doing business ranking ranges from 1 to 190.

18 The ranking of economies on the ease of resolving insolvency is determined by sorting their distance to frontier scores for resolving insolvency. These scores are the simple average of the distance to frontier scores for the recovery rate and the strength of insolvency framework index. 
Table 2. Doing Business in Georgia 2018 (2017, 2016) [out of 190 (189-in 2016) countries]

\begin{tabular}{|c|c|c|c|c|c|c|}
\hline Topics & $\begin{array}{c}\text { DB 2018 } \\
\text { Rank }\end{array}$ & $\begin{array}{c}\text { DB 2017 } \\
\text { Rank }\end{array}$ & $\begin{array}{c}\text { DB 2016 } \\
\text { Rank }\end{array}$ & $\begin{array}{c}\text { DB 2018 } \\
\text { DTF }\end{array}$ & $\begin{array}{c}\text { DB 2017 } \\
\text { DTF }\end{array}$ & $\begin{array}{c}\text { Change in DTF } \\
(2018-2017) \\
\text { (\% points })\end{array}$ \\
\hline Overall & 9 & 16 & 24 & 82.04 & 79.92 & 2.12 \\
\hline Starting a Business & 4 & 8 & 6 & 97.84 & 97.83 & 0.01 \\
\hline $\begin{array}{c}\text { Dealing with } \\
\text { Construction Permits }\end{array}$ & 29 & 8 & 11 & 77.57 & 77.55 & 0.02 \\
\hline Getting Electricity & 30 & 39 & 62 & 84.32 & 83.77 & 0.55 \\
\hline Registering Property & 4 & 3 & 3 & 92.85 & 92.85 &.. \\
\hline Getting Credit & 12 & 7 & 7 & 85.00 & 85.00 &.. \\
\hline $\begin{array}{c}\text { Protecting Minority } \\
\text { Investors }\end{array}$ & 2 & 7 & 20 & 81.67 & 76.67 & 5.00 \\
\hline Paying Taxes & 22 & 22 & 40 & 87.14 & 87.10 & 0.04 \\
\hline $\begin{array}{c}\text { Trading across } \\
\text { Borders }\end{array}$ & 62 & 54 & 13 & 82.43 & 82.43 &.. \\
\hline Enforcing Contracts & 7 & 16 & 78 & 75.97 & 75.97 &.. \\
\hline Resolving Insolvency & 57 & 106 & 101 & 55.59 & 40.02 & 15.57 \\
\hline
\end{tabular}

Source: Doing Business-2018, 2017, 2016. Full Report. Word Bank, http://www.doingbusiness.org [access: 15.05.2018].

The Ease of doing business index ranks countries against each other based on how the regulatory environment is conducive to business operation stronger protections of property rights. Economies with a high rank (1 to 20) have simpler and more friendly regulations for businesses.

The Doing Business project surveys experts concerning the legally required time and costs of regulatory compliance for various aspects of private enterprise - starting a firm, dealing with construction permits, trading across borders, paying taxes, getting credit, enforcing contracts, and so on - around the world. Each year, the Doing Business reports document large numbers of routine business procedures that would take many days.

In recent years, Doing Business introduced improvements to all of its indicator sets. In Doing Business 2015, Resolving Insolvency introduced new measures of quality, while Getting Credit and Protecting Minority Investors broadened their existing measures. In Doing Business 2016, Dealing with Construction Permits, Getting Electricity, Registering Property and Enforcing Contracts also introduced new measures of quality, and Trading across Borders introduced a new case scenario to increase the economic relevance. In Doing Business 2017, Paying Taxes introduced new measures of postfiling processes and Starting a Business, Registering Property and Enforcing Contracts added gender components ["Doing Business 2018 - reforming to create jobs"].

Ease of Doing Business in Georgia averaged 14.90 from 2008 until 2017, reaching an all time high of 24 in 2014 and a record low of 8 in 2013 (chart 1). 
Table 3. Ease of Doing Business in Georgia ${ }^{19}$ (2018)

\begin{tabular}{|c|c|c|c|c|c|}
\hline Georgia Business & Last & Previous & Highest & Lowest & Unit \\
\hline Industrial Production & 20.60 & 21.80 & 35.10 & -5.00 & percent \\
\hline $\begin{array}{l}\text { Manufacturing } \\
\text { Production }\end{array}$ & 0.90 & 24.30 & 41.30 & -4.30 & percent \\
\hline $\begin{array}{c}\text { Changes } \\
\text { in Inventories }\end{array}$ & 512.00 & 139.30 & 512.00 & -261.70 & $\begin{array}{l}\text { GEL Mil- } \\
\text { lion }\end{array}$ \\
\hline $\begin{array}{l}\text { Leading Economic } \\
\text { Index }\end{array}$ & 5.60 & 5.50 & 8.40 & -0.80 & percent \\
\hline Internet Speed & 8774.17 & 8242.93 & 8774.17 & 535.00 & KBps \\
\hline IP Addresses & 508938.00 & 489558.00 & 527752.00 & 40728.00 & IP \\
\hline Mining Production & 0.00 & 10.20 & 119.80 & -66.39 & percent \\
\hline $\begin{array}{l}\text { Competitiveness } \\
\text { Index }\end{array}$ & 4.28 & 4.32 & 4.32 & 3.75 & Points \\
\hline $\begin{array}{l}\text { Competitiveness } \\
\text { Rank }\end{array}$ & 67.00 & 59.00 & 93.00 & 59.00 & \\
\hline Business Confidence & 28.00 & 27.00 & 40.40 & 3.60 & Index Points \\
\hline $\begin{array}{l}\text { Ease of Doing } \\
\text { Business }\end{array}$ & 9.00 & 16.00 & 24.00 & 8.00 & \\
\hline Corruption Index & 56.00 & 57.00 & 57.00 & 18.00 & Points \\
\hline Corruption Rank & 46.00 & 44.00 & 133.00 & 44.00 & \\
\hline
\end{tabular}

Source: http://www.doingbusiness.org (Last updated - May of 2018).

EASE OF DOING BUSINESS IN GEORGIA

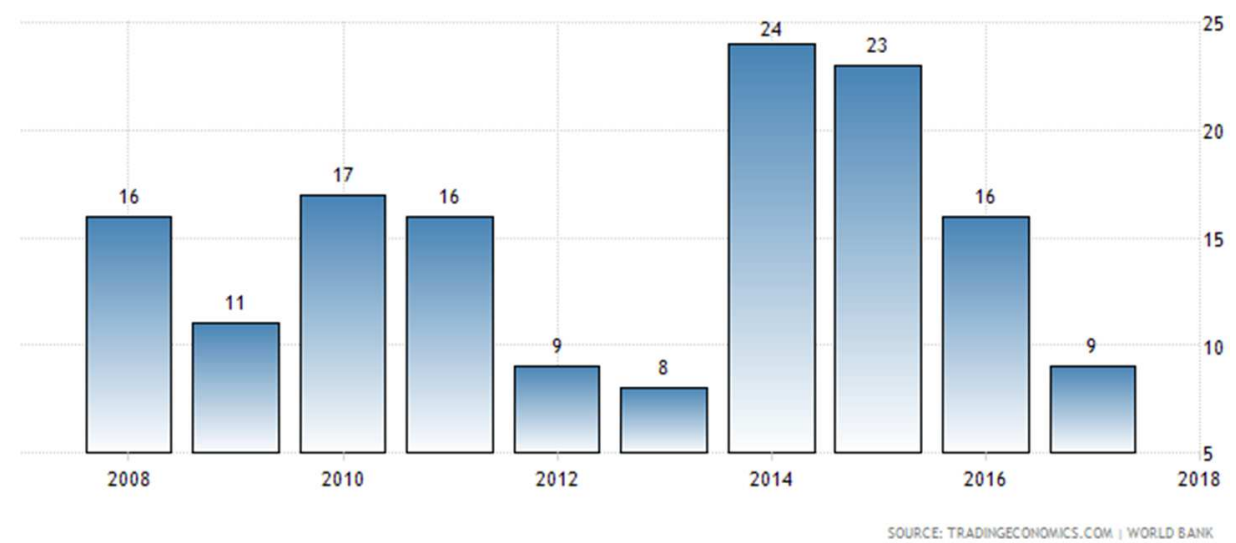

Chart 1. Ease of Doing Business in Georgia (in 2008-2018) ${ }^{20}$

Source: tradingeconomics.com World Bank [access: 15.05.2018].

19 This table includes a chart with historical data for Ease of Doing Business in Georgia. Ease of Doing Business in Georgia - actual data, historical chart and calendar of releases.

${ }^{20} \mathrm{http}$ ://www.doingbusiness.org [access: 15.05.2018]. 
According to the most recent data, good regulatory practices are present in almost all of the world's regions. Aside from 28 OECD high-income economies, the 50 highestranked economies include 13 from Europe and Central Asia, five from East Asia and the Pacific, two from Sub-Saharan Africa and one each from the regions of Latin America and the Caribbean and the Middle East and North Africa. Each region also has a relatively wide spectrum of strong and weak performers. Economies are ranked based on the distance to frontier score. This measure shows the distance of each economy to the "frontier," which represents the best performance observed on each of the indicators across all economies in the Doing Business sample.

The overall measure of the ease of doing business gives an indication of where it is easier for domestic small and medium size firms to do business. Although the economies with the most business friendly regulation in this year's ease of doing business ranking are relatively diverse, the economies within the top 20 share some common features. Fourteen of the top 20 are OECD high-income economies; three are from Europe and Central Asia and three from East Asia and the Pacific. Eighteen of the top 20 are classified as highincome economies. The top 5 performers are New Zealand, Singapore, Denmark, the Republic of Korea and Hong Kong SAR, China. The former Yugoslav Republic of Macedonia is the only upper-middle-income economy on the list, while Georgia is the only lower-middle-income one. To date, no low-income economy has reached the top 20 group. However, being wealthy does not guarantee a front-runner position in the ease of doing business ranking; many high-income economies still have room for progress. Having few bureaucratic hurdles, robust legal institutions and laws and regulations that are based on international good practices is what matters most for a good performance in the ease of doing business ranking.

In OECD high-income economies, for example, New Zealand, Denmark and Korea have the highest overall distance to frontier scores at $86.55,84.06$ and 83.92 , respectively. Georgia has 82.04 (table 1,2). Conversely, Greece, Luxembourg and Chile have the lowest scores in this group, at 68.02, 69.01 and 71.22. However, the OECD high-income group has the smallest gap between the highest and the lowest scores, of only 18.53 percentage points. Sub-Saharan Africa has the widest gap (57.56 percentage points), with a regional average score of only 50.43 - the lowest across all regions. Among the economies of Sub-Saharan Africa, Mauritius has the highest distance to frontier score (77.54), while Somalia the lowest (19.98) ["Doing Business 2018 - reforming to create jobs"].

To start a business in the high-income OECD countries, for example - in New Zeland 1 day, in lower-middle-income country - Georgia 4 day, in South Africa - 136 day. Similarly, following the required procedures to get a construction permit would take an average of 94 days in South Africa, 185 days in Afganistan, 29 days in Georgia, 12 days in Lithuania and 3 days in New Zeland. Clearly, most developing countries of the world do not make it fast or easy to comply with the regulations that govern business.

Researcher-scientists have found benefits associated with improvements in both the overall "Ease of doing business" and its components. Indicators of starting a business (and which is used to calculate methodologically) are: the number of procedures entrepreneurs can expect to go through to start up and formally operate an industrial or commercial business, as well as the time and cost to complete these procedures and the paid-in minimum capital requirement as a percentage of Gross National Income (GNI) per capita (table 4). 
Table 4. Indicator of starting business

\begin{tabular}{|c|c|c|c|c|c|}
\hline \# & Indicator & Georgia & $\begin{array}{c}\text { Europe \& } \\
\text { Central Asia }\end{array}$ & $\begin{array}{l}\text { OECD high } \\
\text { income }\end{array}$ & $\begin{array}{c}\text { Overall } \\
\text { Best Performer } \\
\end{array}$ \\
\hline 1 & Procedure - Men (number) ${ }^{21}$ & 2 & 5.2 & 4.9 & $\begin{array}{c}1.00 \\
\text { (New Zealand) }\end{array}$ \\
\hline 2 & Time - Men (days) ${ }^{22}$ & 2 & 10.1 & 8.5 & $\begin{array}{c}0.50 \\
\text { (New Zealand) }\end{array}$ \\
\hline 3 & $\begin{array}{l}\text { Cost }- \text { Men } \\
(\% \text { of income per capita })^{23}\end{array}$ & 2.5 & 4.4 & 3.1 & $\begin{array}{c}0.00 \text { (United } \\
\text { Kingdom) }\end{array}$ \\
\hline 4 & Procedure - Women (number) ${ }^{24}$ & 2 & 5.2 & 4.9 & $\begin{array}{c}1.00 \\
\text { (New Zealand) }\end{array}$ \\
\hline 5 & Time - Women (days) ${ }^{25}$ & 2 & 10.1 & 8.5 & $\begin{array}{c}0.50 \\
\text { (New Zealand) }\end{array}$ \\
\hline 6 & $\begin{array}{l}\text { Cost }- \text { Women } \\
(\% \text { of income per capita })^{26}\end{array}$ & 2.5 & 4.4 & 3.1 & $\begin{array}{c}0.00 \text { (United } \\
\text { Kingdom) }\end{array}$ \\
\hline 7 & $\begin{array}{l}\text { Paid-in min. capital } \\
(\% \text { of income per capita })^{27}\end{array}$ & 0.0 & 3.4 & 8.7 & $\begin{array}{c}0.00 \\
\text { (113 Economies) }\end{array}$ \\
\hline
\end{tabular}

Source: Doing Business-2018. Full Report. Word Bank [access: 15.05.2018].

\section{DOING BUSINESS IN GEORGIA - FUTURE PERSPECTIVES}

In order to facilitate business, the Government of Georgia has announced a new changes a month ago (March, 2018) to increase the share of small and medium-sized businesses in the country's economy:

- One of them is the unique event in world practice, changes to small and medium entrepreneurs to reduce the symbolic turnover of $1 \%$ - up to $5 \%$. This is about 120 thousand small business entrepreneurs in Georgia;

${ }^{21}$ The total number of procedures required for a married men to register a firm. A procedure is defined as any interaction of the company founders with external parties (for example, government agencies, lawyers, auditors or notaries).

22 The total number of days required for a married men to register a firm. The measure captures the median duration that incorporation lawyers indicate is necessary to complete a procedure with minimum follow-up with government agencies and no extra payments.

${ }^{23}$ Cost is recorded as a percentage of the economy's income per capita. It includes all official fees and fees for legal or professional services if such services are required by law for a married men.

${ }^{24}$ The total number of procedures required for a married women to register a firm. A procedure is defined as any interaction of the company founders with external parties (for example, government agencies, lawyers, auditors or notaries).

25 The total number of days required for a married women to register a firm. The measure captures the median duration that incorporation lawyers indicate is necessary to complete a procedure with minimum follow-up with government agencies and no extra payments.

${ }^{26}$ The amount that the entrepreneur needs to deposit in a bank or with a notary before registration and up to 3 months following incorporation and is recorded as a percentage of the economy's income per capita.

27 The amount that the entrepreneur needs to deposit in a bank or with a notary before registration and up to 3 months following incorporation and is recorded as a percentage of the economy's income per capita. 
- The enterprise with a turnover of 500 thousand GEL will be considered as a small business category (up to now 100 thousand GEL turnover);

- Organization of economic activity will be exempt from profit tax and they Will be transferred to the "Distributed Profit" tax. Exemption from the Value Added Tax (VAT) in Georgia - production of milk and dairy products; Air services, air transportation and aviation works, as well as marine vehicles.

- New also in the used car business - in case of re-export of car dealers, the excise will be returned in $100 \%$ full (it was 50\%);

These changes are aimed at encouraging small and medium businesses to be even more encouraged, and increase the share of small and medium entrepreneurship in GDP. It is expected that in the medium term about $30-40 \%$ will be an increase in the number of people who will benefit from these benefits. This will significantly facilitate the creation of additional jobs, significantly increase the payment base in Georgia and, most importantly, help the government solve two serious problems in the Georgian economy: unemployment and poverty.

\section{SUMMARY}

For any investor it's interesting to answer the question - is it easier to do business in Georgia? If judge the according of last years "Word Bank Doing Business" indicators, it's possible definitely answer, yes - of course, yes.

However, I believe that the success rate achieved in international economic ratings can be further improved. The state policy has a great impact on the development of the country's competitiveness in creating favorable climate of business: Business regulatory legislation has been significantly improved and has become much more liberal. The improvement process demanded frequent change of laws - new laws were adopted, and a number of amendments included in old laws. For example, in the Tax Code, which has been in force since 2005 , it has included about 40 change packages.

In addition, I think small and medium business loan terms (percentages and deadlines) should be also significantly simplified. It's necessary to prepare general instructions and explanations, which will help most small and medium business representatives to apply for them.

\section{REFERENCES}

1. Besley T., Law, Regulation, and the Business Climate: The Nature and Influence of the World Bank Doing Business Project, "The Journal of Economic Perspectives" 2015, Vol. 29, No. 3.

2. De Soto H., The Other Path: The Invisible Revolution in the Third World, London 1989.

3. Development business sector and labor market. Global perspective in labour market, "Amelia" Aneta Siewiorek Publishing House, Rzeszow 2017.

4. Djankov S., La Porta R., Lopez-de-Silanes F., Shleifer A., Courts, "Quarterly Journal of Economics" 2003, 118(2).

5. Djankov S., La Porta R., Lopez-De-Silanes F., Shleifer A., The Regulation of Entry, "Quarterly Journal of Economics" 2002, 117(1). 
6. Djankov S., McLiesh C., Shleifer A., Private Credit in 129 Countries, "Journal of Financial Economics" 2007 84(2).

7. Doing Business 2018 - reforming to create jobs, http://www.doingbusiness.org/reports/ global-reports/doing-business-2018.

8. Elcanon Isaacs, An Analysis of Doing Business, "Columbia Law Review" 1925, Vol. 25, No. 8.

9. Foreign Direct Investment Trends and Statistics. International Monetary Fond. October 28, 2003.

10. Hallward-Driemeier M., Lant Pritchett L., How Business is Done in the Developing World: Deals versus Rules, "The Journal of Economic Perspectives" 2015, Vol. 29, No. 3.

11. Masurashvili I., Past and Future of Business Administration in Georgia, International Conference for Academic Disciplines. Cambridge, Harvard University. USA. May 26-30. 2013, http://ijas2013harvard.sched.org/event/24724800be6a0b109e0ba718553d6344\#. UZUO3KKnzaQ.

12. Phelps N.A., Power M., Wanjiru R., Learning to compete: Communities of investment promotion practice in the spread of global neoliberalism [In:] Neoliberalization: States, networks, peoples, ed. K. England, K. Ward, Malden, Mass.: Blackwell 2007.

13. Rzepka A., Inter-organizational relations and their influence on the innovativeness of enterprises in the Podkarpackie region, Development Economics and Innovation: Challenges and Solutions, Proceedings of Materials of 4th International Scientific and Practical Conference (29-30 September 2017), Tbilisi 2017.

14. Rzepka A., Masurashvili I., Current state of the Business Administration in Georgia and his role in Global Economy, Proceedings in Scientific Conference SCIECONF-2014. Zilina, Slovakia. June 9-13, 2014.

15. Rzepka A., Masurashvili I., Strategic perspectives for Georgian business - an analysis for medium Strategic perspectives globalisation Georgian business - an analysis for mediumsized enterprises in EU and Georgia, "Modern Management Review" 2016, Vol. XXI, 23 (3/2016).

16. Schueth S., Assembling International Competitiveness: The Republic of Georgia, USAID, and the Doing Business Project. "Economic Georgrafy" 2011, Vol. 87, No. 1.

\section{ŁATWOŚĆ PROWADZENIA BIZNESU W GRUZJI - OBECNY I PRZYSZŁY ROZWÓJ}

Stworzenie sprzyjających warunków dla rozwoju sektora prywatnego w taki sposób, aby skorzystały z niego najbiedniejsze części społeczeństwa jest uzależnione od odpowiednich warunków regulacji działalności gospodarczej w ramach których nowi energiczni przedsiębiorcy, bez względu na płeć i pochodzenie narodowe są w stanie otwierać przedsiębiorstwa, mogą inwestować i rozwijać się, tym samym tworząc dodatkowe miejsca pracy. Do prowadzenia działalności gospodarczej wymagane są skuteczne zasady - normy, które ustanawiają i wyjaśniają prawa własności, zapewniają zmniejszenie kosztów związanych z rozwiązywaniem sporów; normy zapewniające przewidywalność transakcji biznesowych i zaufanie partnerów oraz ochronę przed nadużyciami. Kompleksowe kryteria monitorowania rozwoju biznesu zostały opracowane przez Bank Światowy i każdego roku zostaje przeprowadzana ankieta korporacyjna dla menedżerów różnych firm (projekt Doing Business Banku Światowego). Celem badań jest zapewnienie przyjęcia skutecznych przepisów, których informacja jest dostępna dla wszystkich i które są łatwe do zastosowania. 
W artykule autor podjął próbę odpowiedzi na pytanie, które jest interesujące dla wielu inwestorów zagranicznych - czy łatwo jest prowadzić firmę w Gruzji? Aby odpowiedzieć na to pytanie wykorzystano projekt World Bank Doing Business. Celem tego badania jest zapewnienie czołowym przedstawicielom biznesu bazy danych do opracowania polityki i danych publicznych w celu zbadania wpływu systemów regulacji przedsiębiorstw na wyniki gospodarcze, takie jak produktywność, inwestycje, zmniejszenie biurokracji, korupcja, bezrobocie, ubóstwo itp.

Słowa kluczowe: konkurencyjność, strategia kraju, ranking, kryteria oceny, biznes międzynarodowy.

DOI: 10.7862/rz.2018.mmr.16

Tekst złożono $w$ redakcji: maj $2018 \mathrm{r}$.

Przyjęto do druku: czerwiec 2018 r. 